\title{
THE EFFECT OF THE PALAEO-TEMPERATURE REGIME ON
}

\section{PRESENT TEMPERATURE DEPTH PROFILES IN ICE}

\author{
SHEETS
}

(Abstract)

by

N. W. Young

(Antarctic Division, Channel Highway, Kingston, Tasmania 7150, Australia)

\begin{abstract}
The palaeo-temperature regime at the surface of an ice sheet represents the temperature history at a location over some period up to the present. The time span of interest depends on the site under investigation but can be up to 100 or $200 \mathrm{ka}$ BP (i.e. to beyond the last hypsithermal at $120 \mathrm{ka} \mathrm{BP}$ ). Measured temperature-depth profiles can provide information on past surface temperature changes. The detail depends mainly on the time elapsed since the period of interest. Alternatively the measured profile can be used as a sensitive test of the validity of a temperature history reconstructed from proxy data such as measured stable isotope-depth profiles. Such approaches were used by Budd and Young (1983) in their modelling of the temperature and ice-velocity distributions about several deep bore holes in the Greenland and Antarctic ice sheets.

In calculating the present temperature-depth profile for a given site consideration needs to be given to past surface temperature changes whether they be due to changes in elevation, climatic change, or motion through a temperature field. For thin ice sheets of several hundred metres thickness, and particularly those with high snow accumulation rates, the required historical record covers only the recent few thousand years. For thick ice sheets and low accumulation rates, such as the Vostok and Dome C sites, temperature changes before the last glacial maximum and up to 100 or $200 \mathrm{ka} \mathrm{BP}$ must be included. But, because of the diffusive nature of heat transfer processes, short-term variations can be ignored except during the more recent period.

A study was made of the Dome C temperature profile (Ritz and others 1982) to illustrate the various techniques. It was found that with the temperatures
\end{abstract}

measured over only a fraction of the depth it is not possible to distinguish between the effects of different accumulation rates and different rates of surface temperature change. When comparing measured temperatures and a profile calculated with fixed rates of accumulation and surface temperature change, a small (of the order of a few hundredths of a degree) but consistent discrepancy is found at 700 to $900 \mathrm{~m}$ depth. At least part of this discrepancy can be explained by the temperature changes deduced from the stable isotope record (Lorius and others 1979). But the temperature profile at that depth is dependent on the temperature history far beyond the $30 \mathrm{ka}$ record from Dome $C$, and past accumulation rate changes.

At present insufficient information exists to resolve the ambiguities found in the Dome $C$ record. The deep drilling at Vostok to a depth of $2000 \mathrm{~m}$ holds the best prospect at present for describing a past $\mathrm{cl}$ imatic temperature with a corresponding chronology.

\section{REFERENCES}

Budd W F, Young N W 1983 Application of modelling techniques to measured profiles of temperatures and isotopes. In Robin $G$ de $Q$ (ed) The climatic record in polar ice sheets. Cambridge etc, Cambridge University Press: 150-177

Lorius C, Merlivat L, Jouzel J, Pourchet M 1979 A 30,000-yr isotope climatic record from Antarctic ice. Nature 280 (5724): 644-648

Ritz C, Lliboutry L, Rado C 1982 Analys is of a $870 \mathrm{~m}$ deep temperature profile. Annals of Glaciology 3: 284-289 